I Institute of Social and Political Studies of the State University of Rio de Janeiro

(IESP-UERJ) and Fundação Casa de Rui Barbosa, Rio de Janeiro, RJ, Brazil

clynch3@hotmail.com

II National University of Buenos Aires (UBA), Buenos Aires, Argentina

piapaganelli@gmail.com

\title{
THE CULTURALIST CONSERVATISM OF GILBERTO FREYRE: SOCIETY, DECLINE AND SOCIAL CHANGE IN SOBRADOS E MUCAMBOS (1936)
}

\section{INTRODUCTION}

Gilberto Freyre is traditionally identified, along with other important commentators of the I930s, with one of the major turning points in Brazilian thought, moving towards a greater commitment to historical and sociological objectivity and to the critique of Brazil's social formation. His work has also been recognised as belonging to a lineage of authors who, after the rise of the Republic, devoted themselves to the historical review of the social and political formation of the colony and the Empire. Thus Ângela de Castro Gomes (2000) suggests that, without denying the major theoretical and methodological innovation introduced by Freyre in his interpretation of Brazil's colonial legacy in Casa-grande \& senzala (translated into English as The masters and the slaves), his work displays similarities with the collective endeavour of diverse historians active during the first decades of the Republican experiment - concentrated especially at the IHGB (Instituto Histórico e Geográfico Brasileiro) - to rethink the nature of historiographic work and the use of historical methods and sources that went beyond an attempted Republican mythological reconstruction of the Brazilian past. Viewed from a political angle, Freyre has recently been situated within a conservative culturalist line of Brazilian thought, opposed to the modernization promoted both by statist nationalism and by liberal cosmopolitanism (Lynch, 2017). The first work by Freyre to have an impact on Brazilian social thought was Casagrande \& senzala, published in $\mathbf{1 9 3 3}$, in which the author accounts for the forma- 
tive institution of the Brazilian nation as a colony: the patriarchal rural and feudal system, organised around the sugar plantation economy and slave labour, in which social actors circulated who transcended the family nucleus and in which inter-racial relations were characterized by a type of antagonistic sociability that oscillated between intimacy and violence. In Sobrados e mucambos (translated as The mansions and the shanties), for its part, published in I936, we accompany the decline of this same patriarchal society, caused by the rose of a new urban order marked by impersonality. This second book, therefore, replaces the Brazilian cultural ambiguity between patriarchal tradition and the Portuguese influence for the ambiguity between patriarchal tradition and the process of westernization influenced by bourgeois Europe.

The objective of the present article is to comprehend the intellectual production of Gilberto Freyre from the ideological viewpoint. Here we employ the concept of ideology in the weak sense, understood in the plural, as a "set of ideas, beliefs, opinions, and values that exhibit a recurring pattern, are held by significant groups, compete over providing and controlling plans for public policy, and do so with the aim of justifying, contesting, or changing the social and political arrangements and processes of a political community" (Freeden, 2003: 32). The meanings and communicative importance of ideologies can only be determined by ascertaining their syntax (that is, their basic structures and the relational patterns between their components), their conventional uses in a social context and the degree of acceptability of the rules set by it (Freeden, 2003: 43). The three major modern political ideologies are liberalism, socialism and conservatism, the first of which pursues values like reason, individual freedom and progress; the second, the welfare of the collectivity, equality and work; and the third, change within order, respecting the pre-existing traditions. Here we set out from the premise that these three ideologies underwent alterations in being transplanted from Europe to Iberian America and, consequently, to Brazil in particular. The perception of the Ibero-American elites of occupying a peripheral and backward place in the western world subjected these ideologies to a double filter, represented by the binary pairs of cosmopolitanism and particularism, and modernity and backwardness, which conferred them certain particularities. Foremost among the latter is the repetition of certain common themes turning "basically around the diagnosis of national backwardness, barbarity, delay or underdevelopment and the imperative of progress, civilization, evolution or development, means conducive to the transformation of structures inherited from colonization to catch up with centric modernity" (Lynch, 2016: 83).

Comprehending Brazilian political culture as a composite of diverse ideologies, or lineages, or intellectual traditions, the present article thus explores the diverse forms through which conservatism had to respond to the challenges of adapting to a society perceiving itself as peripheral and backward as 
in the case of Brazil. The archetypical conservative ideology is characterized by the belief in the extrahuman origins of a social order taken to be permanent, produced by God, nature, history, biology or the market. Hence its anguish or anxiety in the face of the social changes sponsored by liberalism and socialism, which it perceives as artificial. Conservatism prescribes, then, an adequate form of change, one that would be 'natural,' 'organic,' described as the only legitimate, secure and resilient form. In Brazil, the recent and peripheral formation of its society when modernity was already well under way (the nineteenth and twentieth centuries), as well as the perception of its frailty or incipience, posed conservatives a series of questions and dilemmas around which they were frequently unable to reach a consensus. The fact that they shared an anti-Americanism, a pragmatic vision of history and a distrust of capitalism was not enough to keep them always in harmony, leading them to split into two main strands or lineages.

The first group of conservatives, which we shall refer to here as state reformist, saw the Brazilian social formation inherited from colonization mostly in negative fashion. Its members believed that the nation emerging from the process was weak, spineless or malformed, a diminishment that contrasted with the huge size of the national territory and its immense future potentialities. Aiming to counter such ills and reduce the hiatus between its potential grandeur and present-day smallness, these conservatives applied formulas inherited from Iberian enlightened absolutism, later renewed in a positivist or developmentalist guise. They believed that only the deliberate action of a strong state, guided by a nationalist elite, devoted to the common good, capable of imposing itself through its will and enlightenment, could create national order and, subsequently, nationhood itself, countering the dangers of dissolution or imperialism. This type of state reformist conservatism matches the 'instrumental authoritarian' profile described by Wanderley Guilherme dos Santos (I978): it condemns society's backwardness and aspires to promote a conservative revolution, led from above by a State guided by nationalist and disinterested elite.

Meanwhile, the second group of conservatives tended to see the colonial formation in a more benevolent light, that is, more positively, albeit not without its problems. Despite its vicissitudes, they tended to defend the thesis that the essence of Brazilian society had already been formed by God, nature or history. This conservatism can be called precisely culturalist, because it valorises a past that it qualifies positively as patriarchal, Iberian and Catholic. Described in the tones of a civilizational epic, the colonial formation - Portuguese, Catholic and slavery-based - was seen to have moulded an original culture in America. Thanks to this process, Brazil had developed into a singular society that made it perfectly distinguishable from other great nationalities, turning its population into an authentic people, in accordance with the classic parameters of Hegelian philosophy and nineteenth-century Romantic national- 
ism. While recognizing its problematic aspects, its supporters also saw the positive aspects of this society, principally the singular and harmonious character of its culture, seeking to defend it against liberal, Americanist, individualist and secular cosmopolitanism, but also against the interventionism of national statists, whether conservative or socialist.

The already classic studies of Wanderley Guilherme dos Santos (I978), Bolívar Lamounier (2006) and Gildo Marçal Brandão (2005) on Brazilian political thought primarily focus on the conservative strand that we denominate state reformist and that they have called instrumental authoritarian, authoritarian and organic idealist, respectively. The existence of the second strand, however, seems to have passed them by unnoticed, probably due to their emphasis on the social rather than the political. This has become the subject of increased attention over recent years. In reflecting on the difficulties and specificities in the definition of conservative thought in Brazil during the twentieth century, Bernardo Ricupero (2010: 92) approaches the differences between authors like Freyre and Oliveira Vianna. While, for the latter, the accusation that the rural element was responsible for the 'disorder' of Brazilian society resulted in a rupture with the conservative defence of social traditions and the defence of the State assuming a leading role, for Freyre, on the contrary, the reiteration of the rural and patriarchal aspects of the national formation would make him more fond of tradition, a central element in the classic definition of conservatism, making him one of the few representatives of Brazilian social thought "closest to classic conservatism." Other works have shown how this distinction can be traced back to the nineteenth century. This would suggest, therefore, two different strands of the Brazilian conservative tradition, sometimes allied, sometimes clashing: one of a reformist and statist orientation, the product of enlightened absolutism and represented by authors like José Bonifácio, Bernardo de Vasconcelos, the Visconde do Uruguai, Alberto Torres and Oliveira Vianna, and another strand more closely oriented to the European archetype, which in Brazil acquired Iberianist, patriarchal and Catholic contours, and comprised figures like Azeredo Coutinho, Justiniano da Rocha, José de Alencar, Eduardo Prado and Gilberto Freyre (Lynch, 2017: 315).

The objective of the present work is precisely to deepen our knowledge of the culturalist strand of the Brazilian, Iberianist and Catholic conservatism, turning for this purpose to the work of Gilberto Freyre and, above all, Sobrados e mucambos, a book that while less well-known than Casa-grande \& senzala is nonetheless considered Freyre's best work by some of his most important commentators (Mello, 20I0: 28). Subsequently we seek to perceive how his work, received positively in the modernist, nationalist and anti-liberal context of the I930s due to its revelation of the roots and the 'essence' or 'originality' of Brazilian society, began to be viewed less favourably in the period after the Second World War when the process of massification and democratization of society 
led more radicalized sectors of the expanding middle class to lean towards socialism. The modernist elements of his writings were pushed into the background of analyses, and Freyre became criticized by the socialist-inclined intelligentsia, working in university environments, due to the aristocratic elements embedded in his work. Finally, we look to identify some of the positive aspects of Freyre's culturalist conservatism in a peripheral context that tends to be continually devalued as a society compared to centric models. We argue that the construction of an imaginary of national belonging, in the form of positive shared reference points, was largely due to people like Alencar and Freyre, who fought against statists like Uruguai and Oliveira Vianna for whom the nation was non-existent or spineless, and against liberals like Tavares Bastos and Alberto Sales, for whom the backward state of Brazilian society was such that it could only be recuperated, they argued, by changing identity through a cultural transplant. In the specific case of Freyre, Evaldo Cabral de Melo (2010: 24) reminds us that, in his time, nobody did more "to transform miscegenation from passive to active, from an object of pessimistic lucubrations into a motive for national optimism."

The recourse to an interpretive essay of Brazil as a means to apprehend its underlying ideology does not seem unreasonable to us. Despite the 'scientific' pretension of these essays, all of them had some intention of intervening in the political debate and, as such, belong to Brazilian political thought, understood in the narrower sense as a "a smaller set of more comprehensive, systematic or abstract works, which comprise the canon of 'classics' of our political thought, left by our main political thinkers" (Lynch, 20I6: 87). Generally materialized in books judged to be classics and taking the form of an interpretive essay of Brazil, the works of these authors are seen as the highest expressions of what can be understood as Brazilian political theory and/or a Brazilian political science, in the sense possessed by the latter expression prior to the institutionalization of universities. However 'sociological' some of these works may appear, their aspiration to intervene in public debate is evident and their normative quality or the political values guiding them allow us to identify their ideological profile. Here, therefore, there is no depreciative intention to identify the political orientation of the cited works, which clearly have lost none of their heuristic capacity to interrogate reality. All forms of political thought, however scientific their aim, possess an ideological dimension that derives from an elaborate mixture of rational or scientific elements and others that are emotional or ideological properly speaking (Freeden, 2003: 67).

\section{SOBRADOS E MUCAMBOS: A HERMENEUTICS OF THE BRAZILIAN ETHOS}

The intellectual production of the young Gilberto Freyre was stimulated by the critique of the liberal cosmopolitanism of the First Republic with the objective of preserving and valorising the political and intellectual inheritance of the old 
Pernambuco sugar civilization. Manifesto regionalista and the modernist articles of his youth, published in Tempos de aprendiz, are illustrative of the anti-liberal and anti-democratic inclination that then animated him and many of his contemporaries. Freyre (I996: 56-57) wanted "a sweet aristocracy of manners, tastes, ways of living and feeling," guided by an "ideal of high culture in the service of the malleable and credulous illiteracy of the vast majority, those who by nature are happier obeying effortlessly" (Freyre, I979: 2I). These characteristics marked a central trait of the type of conservatism to which Freyre is affiliated: the idea that the values of a Catholic, patriarchal, rural and pre-capitalist society represented the authenticity of the national tradition. The narrative of the emergence of individualist universalism is, therefore, a narrative of the decline of Brazilian authenticity. Freyre (I996: 80) praised the mucambos or shanties, the Portuguese architecture, the tropical climate, its narrow streets, women's vocation for the kitchen and religion, recognizing that in the case of all of them, the "regional awareness and traditional meaning of Brazil have been disappearing under a wave of bad cosmopolitanism and false modernism. It is regional culture as a whole that needs to be defended and developed." It is important to understand here that Freyre's traditionalist posture is not in the least incompatible with the somewhat reactionary flavour of this era, including the admiration shown for famous authors of the period such as Charles Maurras and Maurice Barrès. In other words, during a period when to be antiquated was to be liberal, being a reactionary was as modern as being a Bolshevik. The political activism demonstrated by Freyre during this period soon receded following the I930 Revolution, when the increase in political participation through the incorporation of the middle class ended any hope of restoring the aristocracy.

It was at this point that Freyre abandoned pursuit of a political career and focused his efforts on producing a work that would dialogue more deeply with the historical and social science of his time. The first result of the young Pernambuco intellectual's efforts was Casa-grande \& senzala: formação da família brasileira sob o regime da economia patriarcal, one of the great classics in the interpretation of Brazil, published in I933, whose impact was simply overwhelming. In the book, Freyre presents a social history of the Brazilian family based on the slave-owning patriarchal archetype that characterized it under the old colonial regime. Transformed into a core explanatory category in the nation's formation, the slave-owning family (the casa-grande, manor house) was considered by Freyre (2002: I30) the nucleus of the country's civilization: the manor houses had been the force responsible for maintaining the country's moral unity, they were "centres of patriarchal and religious cohesion," serving as "points of support for national organization." They comprised an "immense feudal power" (Freyre, 2002: 132) that exercised all the social functions possible at the time: "fortress, chapel, school, workshop, holy house, harem, convent, lodging" (Freyre, 2002: I34). Freyre's conception of the formation of Brazilian society and his es- 
say-like style in analysing are based, therefore, around three elements that would permeate his entire work and prove fundamental to Casa-grande \& senzala: the patriarchy, the interpretation of cultures and the tropical. The patriarchal family, more precisely the family model typical of the sugar-producing Northeast, was constituted by bonds that went beyond blood ties and through which a heterogenous series of actors circulated: slaves, bastards, adoptees, chaplains, employees, etc. In this sense, the house was far more than just the family home: it comprised a key institution for understanding Brazilian colonial society. Casa-grande \& senzala describes the almost feudal domination of the patriarchal rural owner of the sugar plantation: the women and children from his family resided in the manor house, the slaves in the senzala, the slave quarters; buildings that acquired a not only architectural meaning, but also a symbolic one representing an entire autonomous lifestyle. The senzala was the ideal type, social and ethnic, opposite that of the manor house, with which it maintained a system of antagonisms held in check or balanced by domestic intimacy, including sexual, and by the "conditions of fraternization and social mobility peculiar to Brazil" (Freyre, 2002: I97). Freyre radically innovates by providing the reader with a vision of Brazilian society as hierarchical, original and positive, and, at the same time, integrated and resigned to its conflicts. In this way, the author offers what, in the words of Ricardo Benzaquen de Araújo (I994: 30), constitutes "the bases of a true collective identity, capable of stimulating the creation of a unique feeling of community by making explicit the bonds, until then unsuspected, between the different groups making up the nation."

Published in 1936, the book Sobrados e mucambos: decadência do patriarcado rural e desenvolvimento urbano is presented as a continuation of Casa-grande \& senzala, shaped by its underlying arguments and use of its same frameworks (Freyre, 2002: 665). In this work, Freyre describes the form through which the patriarchal society, organised around the sugar mill in the colonial period, began to disintegrate following the arrival of the Portuguese royal family in Rio de Janeiro in 1808 , eroded by foreign influence, on one hand, and the continuous increase in the urbanization of the country, on the other. The first edition contained one paragraph and seven chapters: "How the social landscape of patriarchal Brazil changed during the eighteenth century and the first half of the nineteenth century"; "The sugar mill and the square"; "The house and the street"; "The father and the son"; "The woman and the man"; "The townhouse and the shanty"; "The Brazilian and the European"; "Rise of the graduate and the mulato." Sobrados e mucambos foregrounds the period of transition from the manor house (rural residence of the colonial Brazilian aristocracy) to the sobrado, the townhouse or mansion (urban residence of the Brazilian aristocracy); and from the senzala (dwelling place of the slaves on the sugar plantations of colonial Brazil) to the mucambo, the shanty (precarious residence of former slaves). And since in Freyre the intimate/domestic (i.e. private) sphere is presented as a syn- 
ecdoche of Brazilian society, as public life, both books presume the transition from sugar to industry, from farms to cities, from colonial traditions to modernity and from aristocracy to the bourgeoisie, with the consequent social impacts of these changes. Hence the narrative of Sobrados e mucambos accompanies and constructs the image of the progressive advance of modern individualism as a regulator of social relations in substitution for the organic relation represented by the Brazilian patriarchal model.

The changes are traversed by a dynamic of passional, sexual, exuberant and unequal sentimentalism, which is linked to the distinctive feature of Portuguese colonization in Brazil, its Moorish cultural roots and its adaptation to the tropical climate. Even so, the presence of the house, as a category of the private, allows us to understand Freyre's conception of race and culture (2013: 22) by arguing that: "The house is, in fact, the most important centre of adaptation of man to the environment." This supposes the use of the concept of race as an effect more than a cause of the combination of environment and culture. For Freyre, then, race was a cultural transformation modified and adapted to the environment, not a determinist element that conditions the social relations, moral and psychological characteristics and cultural legacy of miscegenation. As Elide Rugai Bastos (2006: 132) reminds us, Freyrian culturalism, a legacy of Boas and his American experience, allows us to "discern in the anthroporacial object of study its potential development into anthroposocial." For this reason, it was in his work that, for the first time in the history of Brazilian social thought, the civilizational contribution of the black population was recognized (DaMatta, 2013) by breaking with the biologicist paradigm, since he sought to base his argument on culturalism, though he did not succeed in freeing himself entirely from the influence of the racial vocabulary left behind by nineteenth-century theories (Costa Lima, I989). Freyre thus works ambiguously with the concept of race insofar as he gives the impression that he does not wish to adhere to its usual sense. Indeed, while in Casa-grande \& senzala he studied Brazil on the basis of its formative races, highlighting its racial mixture and tropical climate as vital components of the future Brazilian ethos, in Sobrados e mucambos the categories that structure the text are now cultural, not biological or geographical, dualities (DaMatta, 2013):

Distinguishing race from culture and thereby valorising the contributions of the Negro, the Portuguese and - to a lesser degree - the Indian on an equal footing, our author is able not only to overcome the racism that had been significantly organizing Brazilian intellectual production, but also to construct another version of national identity in which the obsession with progress and reason, the integration of the country in the march of civilization, was to a certain point replaced by an interpretation that paid some attention to the hybrid and singular articulation of traditions that took place here (Araújo, 1994: 28).

Ricardo Benzaquen de Araújo (I994), one of the most prominent specialists in Freyre's work, argues that the critiques directed at the author revolve 
around the particular ambiguity with which he employed the categories of race and culture. For example, Freyre mentions the Portuguese, Jews and English in cultural terms, but the dimension of the Aryan race is absent. At the same time, he makes use in his descriptions both of physical and geographic features and of cultural features when discussing the black slaves. Benzaquen exposes this apparent ambiguity when he argues that Freyre's viewpoint is informed by a neo-Lamarckian conception of race (Lamarck represented the ultimate link between social theory and biology) which supposes an unlimited aptitude of human beings to adapt to the most diverse conditions of the physical environment. Thus:

Although he also does not refrain from mobilizing the interaction between races, physical environment and culture, Gilberto Freyre does so in order to demonstrate the superiority of the influence of social structure over the racial structure and the physical environment. Hence his notion of the tropics is opposed to geographic and climatic determinism, since it also implies the affirmation of the modifying influence of culture on nature (Botelho, 2010: 57).

Freyre's Brazil is not defined by its absences and deficiencies compared to other civilizational models, but positively through its original features. By resorting to racial paradigms to interpret Brazilian society, Freyre founded an ethnography of everyday life in Brazil that took into consideration its most singular aspects, the product of a particular miscegenation that allowed many diverse traits to coexist in intimate but antagonistic form. Especially because he took the house as a category of sociocultural analysis, demonstrating the symbolic importance of the family and the way in which interpersonal bonds have been established since Brazil's colonial era.

\section{PRESERVING BRAZILIAN SOCIABILITY: THE CONSERVATIVE VOCATION OF SOBRADOS E MUCAMBOS}

The ideological mainstream in the I 930 s was dominated by conservatism, represented by the reformist statism of Oliveira Vianna, whether through the traditionalist Catholicism of Tristão de Athayde or the modernist culturalism for which Gilberto Freyre would become the foremost icon, followed closely by Sérgio Buarque de Holanda of the first edition of Raízes do Brasil (Feldman, 20I6). The latter strand amounted to a modernist Iberianism, which combined the valorisation of elements of colonization with an anti-liberal and anti-statist, but nonetheless modernist, approach - that is, attributing a residual or instrumental importance to Catholicism. As such, they clearly distinguished themselves from another strand within culturalist conservatism: the neo-Thomists and traditionalists, like the aforementioned Tristão de Athayde and Hamilton Nogueira, for whom Brazilian culture was primarily defined as Roman Catholic and was vehemently opposed to modernism, when not modernity itself.

Sobrados e mucambos describes the gradual decline of the old rural patriarchy of the colony in its multiple aspects, exposed to the sweeping influx of 
European influences and the competition of commerce, banks, the State, the Church, factories and colleges - all symbolized by the street and the square (the public and impersonal). The emergence of the public sphere occurred, therefore, in Brazil, simultaneously with the decline in the country's authentic formation: the townhouse replaced the manor house; the shanty replaced the slave dwellings. The feudal political organization and frondeur that had characterized the colonial regime (Freyre, 2002: 768) gave way to monarchist centralization, especially under the Second Empire. Capitalism, statism, college education and cosmopolitanism, all represented by Dom Pedro II, eroded the foundations of the old rural aristocracy. Previously hidden away at home, women began to receive visits and appear in certain social circles. Children began to study in religious colleges and soon challenged the authority of the priests. Converted into graduates, they preferred the more foreign and cosmopolitan city world to the organic life of the sugar plantation of their parents. They had become "French-influenced, urbanized and civilized" (Freyre, 2002: 737). Social stratification was made more complex by the timid emergence of a middle class between the manorial and slave castes, represented archetypically by the bacharel mulato, the mixed-race graduate. A reconfiguration took place, therefore, of the system of antagonisms in equilibrium that had reigned during the colonial and rural period, reinforced by a process of Europeanization that caused society to lose its old oriental aspect. The backdrop to the Freyrian narrative is the idea that the material and moral progress of modern western civilization - governed by the principles of the public, the urban and individualism - dissolved the antagonistic balance on which Brazilian society had once been sustained. But the new cosmopolitanism never triumphed entirely over the old and organic. Patriarchal habits adapted to the city but did not vanish: "The drama of the disintegration of the power, for a while almost absolute, of the rural pater familias in Brazil was not so simple, nor the rise of the bourgeoisie so rapid" (Freyre, 2002: 738). "Brazilian patriarchalism, moving from the sugar plantations to the townhouses, did not surrender immediately to the street; for a long time the house and the street were virtual enemies" (Freyre, 2002: 750). The woman of the townhouse began to enter public life, "albeit little-bylittle" (Freyre, 2002: 755); she continued to be abused by her father and her husband, "less, however, than in the manor houses of the farm and plantation" (Freyre, 2002: 835). Examples like these can be multiplied by the dozens.

From the political or ideological viewpoint, with its flagrant nostalgia for the past order, the conservative vocation of Sobrados e mucambos is undeniable, revealing the attraction for the hierarchical order, whose antagonisms of race, gender and class became balanced and harmonized through the interpenetration of cultures, resulting in a kind of hybrid, typically Brazilian sociability. The patriarchal organization is described by Freyre (2002: 659) as "a near marvel of accommodation: of the slave to the master, of the black to the white, of the son 
to the father, of the woman to the husband." While patriarchalism, as Rugai Bastos (2005: 26) reminds us, is treated by Freyre as the factor responsible for national unity and for the survival of the organic forms of Brazilian society, the modernizing aspects that, in the work of commentators like Sérgio Buarque de Holanda, were essential to overcoming the fragility of Brazil's formation, are seen by Freyre as factors in the disintegration of authentic solutions in order to enable the nation's formation on the periphery of modernity. In this sense, Freyre was evidently concerned with the survival of a kind of pre-political sociability held to be essentially Brazilian, whose singularity had been under attack from the process of modernization inspired by exogenous culture (British, French or US), expropriated by the nation state. This preoccupation led him to become interested in the present or the future insofar as they reflected or failed to reflect the past. Modernization accentuated contradictions, creating new conflicts that had to be compensated were possible by other forms of social fraternization: the parade, the church festival and carnival (Freyre, 2002: 660). Among the new urban graduates, modernization fomented a bookish and academic education, alienated and feeble, in various aspects inferior to the education of the old rural patriarchs: organic, practical and healthy (Freyre, 2002: 795 and 838). The political alienation of the Brazilian elites from reality dated from this period:

Brilliant and literate young men, they lacked, however, that good down-to-earth sense, that equilibrium, that solidity, that view of things that one only gains with experience, that deep political realism of the majority of the captain generals sent by the Portuguese government to its American colony (Freyre, 2002: 768).

The modernization of this stage is described, therefore, as being underpinned by the skilled mulato (mixed-race) worker demanded by the new market - that is, through the social ascension of new elements in manual jobs seen as undignified by the white population. Another path of social ascension available to the mulato was education, in opposition to those engaged in manual/artisanal work. This mulato became employed in jobs required by the new state structure, competing for employment with white people, the reason why Freyre speaks of the 'cordiality' typical of the socially-rising mulato to 'compensate' for the negative fact of his colour. This compensation, at the same time as it affirms racism, shows that the obstacle was relative, not absolute. In other words, it could be overcome through individual talent, showing that leeway existed for forms of social recognition based on differential performance, not only categories linked to phenotype (Souza, 2000: 94). This process of integration of the mulato into Brazilian society allowed, therefore, over the course of the nineteenth century, mulatos to become key figures in the country's literature, politics, army and even the presidency of the Republic. Nonetheless, as a correlate this process had the proletarianization and demonization of the black population, living in segregation in the shanties (mucambos): 


\begin{abstract}
As the country became urbanized, these antagonisms acquired a new intensity; the equilibrium between the whites of the townhouse and the free pretos, caboclos and pardos [black, indigenous-white mixed race and brown populations] of the shanties would not be the same as between the whites of the old manor houses and the negros of the slave dwellings. True, while the antagonisms intensified, the opportunities for social ascension also increased for those slaves and children of slaves in the cities with artistic skill or extraordinary intelligence or special qualities of sexual attraction. And miscegenation, as widespread in the cities as on the farms, softened, in its own way, the antagonisms between the extremes (Freyre, 2013: 168).
\end{abstract}

Another problem posed by modernization for the conservative, nationalist or regionalist was how to modernize without denaturing and disfiguring the nation. On this point Freyre's displeasure is clearly evident. On one hand, there was the modernization promoted by foreign democratic liberalism, which, during the Empire and the First Republic, had eliminated national traditions. In I930 the nationalist theses emerged victorious. Freyre's adversary in terms of the modality of modernization was the national statism of authors like Oliveira Vianna, who revived the typically Ibero-American belief, founded on the tradition of enlightened despotism, that the State should serve as the spearhead of modernization. Imposing the latter from above through an act of political will. This nationalist and centralizing interpretation envisaged the State as the protagonist of modernization, competing against the colonial and traditional aspects of Brazilian society. This thesis was one that Gilberto Freyre vehemently rejected, since, for him, Brazilian society had been formed around the patriarchally organized family, the work neither of the Portuguese nor the Brazilian State. Hoping to promote from above a flight into the future, authoritarian progressivism failed to respect the material and cultural heritage of the past and, with it, civil society's own rhythms, preventing the latter from evolving in a more organic way free of outside interference. Brazil should not, therefore, confront its present challenges by employing the State to destroy the past in the name of modernity. Instead society should be modernized in accordance with its own rhythms with the State limiting its actions to preserving and promoting the pre-existing national identity against foreign influence. The pace with which the modern foreigner was being welcomed in the country should be curbed in order to allow a suitable hybridization or accommodation with the legacy of the past. That is how it had always been, Freyre argued. It amounted to a peculiar dynamic in which the new and the traditional always eventually adapted to each other.

While for Freyre the "amalgam of cultures" occurs within the patriarchal family (Bastos, 2006: I03), it is patriarchalism, not the centralizing and tutelary State, that unifies and informs Brazilian society. The mulato, as an intermediary class and the protagonist of the process of democratization of Brazilian society, such as presented in Sobrados e mucambos, illustrates the moment of tran- 
sition between patriarchal society and the emergence of conflicts characteristic of urban and individualist society. Hence patriarchal society - not the action of the centralizing State - was the authentic element in the sociocultural constitution of Brazil that assured its social cohesion and unity over the centuries.

With or without the favour of the State or the Church - with which it clashed more than once - this system was the most constant and widespread dominant power or influence - economic, political, moral, social influence - in our formation [...] always the domain of the family, the economy, the patriarchal organization that rarely had another type of family, economy or organization able to compete with it for predominance over Brazil's formation (Freyre apud Bastos, 2006: 107).

As we mentioned above, it is the figure of the State in the person of Dom João IV, bringing with it the elements of 'bourgeoisation' of Brazilian society, that transformed the nineteenth century into a period of conflict and transition. The Brazilian "likes the street, but the shadow of the house accompanies him"; "patriarchal or semi-patriarchal privatism still dominates us" (Freyre, 2002: 664665). It was through this sociologically enhanced and respectful process of social conventions that social change should continue to unfold, always conducted by those who Freyre dubbed the revolutionaries of order. Freyre was not opposed to innovations, of course, as long as they maintained a relation to the legacy of the past. The new should adapt to the old whenever possible. What had been positive about the past and lost should be restored while preserving what had been maintained. Innovations per se should only redress those aspects of the past that Freyre identified as negative: the predatory exploration of nature, the dependence on monocultures, the lack of individual solidarity, the irresponsibility and violence of private command (Freyre, 2002: 730, 739, 756). In this way, the old ideal of a paternalist or tutelary aristocracy could and should be adapted to the needs of a modern democracy.

Given the need to update the material in a context very different from the one in which it had originally been written, in I95 I Freyre published a second edition that ended up almost double the size of the first. In addition to a preface, the author wrote a long introduction to the second edition and divided the work into two parts. The first contained the first six chapters of the first edition, plus a new chapter inserted between chapter five and the former chapter six, continuing on from the previous chapter, entitled "More on the townhouse and the shanty." The second part combined the former chapter seven, now the eleventh, and four additional chapters: "Race, class and religion"; "The East and the West"; "Slave, animal and machine"; and "Concerning a systematics of miscegenation in patriarchal and semi-patriarchal Brazil." The second edition of the work was conceived as the second volume of a tetralogy entitled Introdução à história da sociedade patriarcal no Brasil [Introduction to the history of patriarchal society in Brazil], to which was added some years later, in I957, Ordem e progresso: processo de desintegração das sociedades patriarcal e 
semipatriarcal no Brasil [Order and progress: the process of disintegration of the patriarchal and semi-patriarchal societies in Brazil]. The fourth and final volume, Covas e jazigos [Pits and sepulchres], never written. The work as a whole can be seen to examine the colony (I500-I822) in Casa-grande \& Senzala, the Empire (I822-I889) in Sobrados e mucambos and the First Republic or Old Republic (I 889I930) in Ordem e progresso (I959). The connecting thread of the published trilogy is a hermeneutics of the Brazilian ethos and its sociological particularities, understood through the passage from a form of inter-racial sociability marked by intimacy and violence to another marked by exclusion and impersonality. The new edition was enthusiastically greeted by sociologists like José Arthur Rios (I996: I40): “The work is a landmark in the historical discovery of Brazil and in the awareness of the urban Brazilian as a historical being, a unique protagonist, between shanties and townhouses, from a drama of universal proportions."

\section{THE CHANGE IN INTELLECTUAL CLIMATE IN THE POST-WAR PERIOD: THE LEFT-WING CRITICS OF GILBERTO FREYRE AND THE GRADUAL CHARACTERIZATION OF HIS WORK AS CONSERVATIVE}

In a context like the Vargas Era, when liberalism was practically banned from intellectual spheres, the dominant ideology was nationalism, whether the statist modality of Oliveira Vianna and Virgínio Santa Rosa, or the Iberian culturalism of Gilberto Freyre and Sérgio Buarque de Holanda. Others like Almir de Andrade sought to synthesize the two modalities, creating a precedent that would bear fruit in later decades (Feldman, 2016). The most celebrated author, though, was Freyre himself. The 'modernist' element present in his works, especially in the frank way in which he described social relations in all their intimacy, prevented the remaining liberals and emerging socialists from perceiving him as an adversary. Such is suggested by Antonio Candido (I 993, p. 82): "For my generation, he functioned in the I930s and I940s as a master of radicality. what fascinated us was the extremely liberated manner in which he dismantled the solemn conception of social history, talking with a delicious freedom about sex, family relations, food, clothing."

The conservatism underlying Freyre's modernism only began to be detected and denounced after the Second World War with the sudden boom in industrialization and urbanization, forcing the rapid democratization of society, which seemed to open up a new era for the country. The growing desire to make a clean slate of a past perceived as hierarchical and unjust deepened among those sectors of the middle class increasingly committed to socialist ideology. In a context where the social sciences where becoming established as university disciplines, led by heads of school who projected themselves as intellectuals with the technical knowhow to make strategic use of social reform in a democratic era, the virtual consensus that had once surrounded Freyre 
began to dissolve. The modernist elements of his culturalism, which had so enthralled the 'sociologists' of the I93os, were pushed into the background of the analyses made around twenty years later. Professional sociologists committed to social change then began to emphasize the conservative or aristocratic aspects of his culturalism. Their understanding was that Brazil could and should no longer be explained by impressionist interpretations of a conservative bent, elaborated by generalist intellectuals, the representatives of old and decadent elites who still exuded an aristocratic air. Even more so if they were Northeasterners.

On the other side, in the camps of the national statist tradition, fallen into temporary disgrace after the fall of the New State, the critics of Freyre's culturalism initially went after their old enemy, whose dethronement from the position of Brazil's principal sociologist provided a chance to settle old scores, one they took eagerly. In Instituições políticas brasileiras, published in I949, a work in which he berated the hegemonic Americanism, Oliveira Vianna (I974: 48) also attacked Freyre for the antipolitical character of 'pan-culturalism,' defined as "an omnipresent and omnipotent entity, the sole explaining factor in the formation of man and civilization. A metaphysical entity or divinity, nothing can exist outside of culture and culturalist causality." Opposing the author of Sobrados e mucambos, Oliveira Vianna argued that although culture exists in society, outside of ourselves, it also exists within us, at a conscience level, and thus is not absolute to the point of functioning as an insurmountable obstacle to human agency. Endowed with enlightenment, will and civic-mindedness, the great statesmen placed in charge of the State, by using their authority, were always capable of breaking the stability of cultural complexes to promote social change and the advancement of society through political action.

In the mid-I950s, adapting the nationalist tradition to the growing democratic configuration of the period, Guerreiro Ramos (I995: 287-288) attacked Freyre's culturalism from a similar angle, questioning the scientificity of a sociology like Freyre's that deployed categories like 'national character,' 'soul,' 'spirit,' 'vocation,' 'race' or 'cordiality.' In his view, the author of Sobrados e mucambos had allowed himself to be carried away by a full-blown entelechy when he attributed the Brazilian people with "a character, a vocation, or fixed tendencies and inclinations," through analyses of what the people had been in the eighteenth century. A dynamic interpretation of history showed that the Brazilian people was still being formed. At that moment, the population was passing through a process of metamorphosis unleashed by industrialization and urbanization, which would lead it to higher levels of civilization, losing the characteristics that Freyre had attributed to it. What most bothered the head of sociology of the Higher Institute of Brazilian Studies (Instituto Superior de Estudos Brasileiros - ISEB) was the way in which the Pernambucan had approached the question of the black population in Brazil. The author of Casa-grande \& 
senzala had not seen black people as a dynamic component of the nation, but as a picturesque and mummified element, a leftover of the colonial period; "something strange, exotic, problematic" (Ramos, I995: I89). Like his master, therefore, Guerreiro criticized Freyre for petrifying with his culturalist essentialism the possibility of social change through political action - with the difference that, instead of great men, it would now be the work of the actual people, increasingly aware of their national potency.

Critiques of Freyre's work for its culturalist conservatism also issued from the Faculty of Philosophy, Letters and Human Sciences of the University of São Paulo, whose social scientists were also inspired by the production of critical sociological knowledge, socialist in orientation, though distinct from that of the capital of the Republic, due to its cosmopolitan or foreign dimension. Young scholars like Antonio Candido (apud Mota, I977: I30) complained: "Look at our master Gilberto Freyre - to what point he is taking his culturalism. His latest works decline into the most lamentable social and historical sentimentalism; into conservatism and traditionalism..." In the following decades, the São Paulo School of Sociology, headed by Florestan Fernandes, also began, like Guerreiro Ramos, to refute Freyre's hypothesis that Brazilian society was some kind of racial democracy (Ricupero, 2010: 97). After I964, the widespread attack on every kind of conservatism led socialists like Octavio Ianni (I989: I I I) to list the statists and culturalists on the same side, representatives of a supposed 'Prussian path' of Brazilian modernization, keen to divest the people of any and all possibility of popular intervention: "This is the basic direction taken by the thought of Oliveira Vianna, Francisco Campos, Gilberto Freyre, Miguel Reale..." Carlos Guilherme Mota (I977: 74) was another robust critic of Freyre's work, qualifying it, from the viewpoint of radical thought, as oligarchical and "produced by a child of the Old Republic," belonging to a "an aristocratizing elite that had been losing power."

The expanding horizon of expectations in the I950s and I960s failed to push Freyre in a more politically progressive direction. On the contrary, he seems to have been ever keener to show off his political thought, proximate to that of Burke. A typical example occurred in the mid-I950s when Freyre, federal deputy for the National Democratic Union, was interrupted during one of his speeches by Daniel Faraco, irritated by the excessively historical approach with which his Pernambucan colleague had resolved to treat the subject under discussion. What was needed, Faraco advised, was to "decide on the present and the future." Freyre (I994: I 23) responded to the interruption without blinking: "That's where you're wrong Your Excellency. The past never went away, the past continues." In I96I, he reiterated the patriarchal, Catholic and Iberian premises of his own interpretation of Brazil: "A civilization was formed among us Brazilians in which the sociologically Christocentric Family comprised the civilizing unit; the main economic factor; the base for an expansion that the 
State merely sanctioned or confirmed" (Freyre, 2002: 653). And he warned that any reform of Brazilian society should respect this earlier formation or risk failure. In an interview given decades later, Freyre would touch on the subject of his conservatism in a more direct and fearless form:

I am frequently accused of being conservative. But what do I want to conserve in Brazil? Brazilian values that are embodied principally in the popular forms of culture, regional forms, that gave a national meaning to Brazil. I am a conservative because I am a nationalist, a conserver of those values that express a Brazilian nation through a Brazilian popular culture. I have valorised this popular culture as much as possible, though not without valorising an elite culture too (Freyre apud Bastos, 2005: 33).

Far from playing dead, Freyre also responded strongly to his critics. He repeatedly denounced the attacks made by his colleagues of a socialist, social democratic or Marxist orientation, and counter-attacked whenever he could, especially after the Cuban Revolution and the João Goulart government accelerated the process of ideological radicalization in the country. Thus, in the preface to the third edition of Sobrados e mucambos (I96I), Freyre bitterly recognized the growing critiques of his work by commentators of Brazil like Caio Prado, Astrogildo Pereira and Werneck Sodré, attributing them to "ideological motives." His strategy was to turn to his description of the modernist Iberianist to describe himself either as an anarcho-traditionalist or as a revolutionary of order; someone who creatively reconciled the two elements only incompatible in the mind of Marxists, who were the real archaic or outdated ones. The future belonged to those who knew how to reconcile "tradition with modernity" (Freyre, 2002: 656). The same strategy resurfaces in the preface to the $\mathrm{I}^{\text {th }}$ edition of Casa-grande \& senzala (I964), in which he accused his Marxist adversaries of attacking him in "more or less violent outbursts," steeped in ideological preconceptions and orientations that were "above all anti-colonialist and anti-Iberian," informed by "largely outmoded philosophies of history" (Freyre, I967: CXIX). By then, impressed by his eulogy for the malleable capacity of the Portuguese to adapt to the tropics, his 'Lusotropicalism' had already been appropriated and disseminated by the Salazar dictatorship to defend the Portuguese colonial empire. On the other hand, the alliance of the statist and culturalist conservatives at the time of the I 964 coup d'état around the banner of anti-communism and antiliberalism would lead to the formation of an ideological block in support of the military regime, which mixed elements of both strands to justify the regime, exhorting the need to defend national, family, harmonious and Christian culture. Freyre would be the figurehead for this bloc.

\section{CONCLUSION}

In this article we have shown Gilberto Freyre to be a major twentieth-century representative of a minority strand of Brazilian conservatism, the culturalist strand, characterized by its extolling of the Iberian and Catholic heritage, whose 
major nineteenth-century representative was José de Alencar. Three points should be underlined in conclusion. The first is the need to confirm the ideological affinities between both authors, already cited in our introduction in order to characterize the elements of this tradition that, in a later work, might be explored in relation to other figures such as Justiniano Jose da Rocha and Eduardo Prado. During the Empire, Alencar was the main reader of Burke to offer a 'traditionalist' interpretation of Brazil's social and political formation. The defence of a prudent form of social progress attentive to 'local preconceptions' led him to valorise the national traditions, including the eulogy for Portuguese colonization, life on the large rural properties and the kind of sociability inculcated by slavery. In characteristic fashion, he attacked both the cosmopolitan liberalism that was disfiguring Brazilian society, making it increasingly French or American, and the statism imposed from above in the attempt to modernize it (Lynch, 2017: 354).

Freyre not only followed the same path, he also left pages in which he admitted the influence of this conservative, Iberianist and Catholic vision, absorbed from an early age in his readings of Alencar. Typically enough, the author of Casa-grande \& senzala tended to discern, in the mixture of traditionalism and modernism of the Ceará writer, a version of his own Lusotropicalism avant la lettre. It should also be remembered that Alencar and Freyre were also devote Anglophiles who much admired English conservatism, which provided them with a model that they could fill with specifically Brazilian content (Burke, 2005). In other words, the idea was to be conservative in the way that an Englishman would be were he Brazilian. In the case of the author of Casa-grande \& senzala, this meant substituting whisky with sugar cane rum, phlegm with cordiality, asceticism with sensuality. The Brazilian conservative should respect the customs of an unequal society, undoubtedly, but actualized with the intimate weaknesses of its components, racially tolerant, morally weak, irreverent or formalist vis-à-vis the sacred, sexually free and so on. In painting this portrait of Alencar, Freyre inevitably ended up providing a description of himself:

A social critic of the slave-owning and patriarchal Brazil of his time, Alencar was not part of the flock who allowed themselves to be dominated by a systematic opposition to everything that was patriarchal, slave-owning and almost feudal in Brazilian society of the time, perceiving only the beauty of the social organization and cultural enchantments found in the triumphantly bourgeois Europe and in the United States, equally bourgeois in its national ways of being. His modernism was not so strong that it extinguished his critical equilibrium or closed him off from any traditionalism; nor did it leave him content with the bourgeois values triumphant in Europe and Portuguese America. It may have been in his own Anglophile way [...]. But he always kept both feet firmly on the Brazilian ground (Freyre, 20IO: I46-I47).

Secondly, we believe it is important to deepen the study of the culturalist conservatism not only because it comprises a distinct tradition of Brazilian political thought, but also due to its actuality. Culturalist conservatism has resur- 
faced after almost 30 years of banishment, on the margin of the progressivist consensus that followed the end of the military regime as a response to its authoritarian practices and human rights violations. The long hegemony of the left in federal power, with its nationalist, socialist, statist orientation and redistributive and gender policies, followed by a deep economic crisis, created the conditions for its re-emergence. This has occurred in a new context in which the statist tradition has been entirely absorbed by the socialists, while its conservative strand has vanished. Only the culturalists have been left to occupy the conservative field, in an opportune alliance with market liberalism. Many observations can be made concerning this unforeseen resurrection. The expectations have been thwarted of those scholars who, believing that the ideologies have exclusively class origins, presumed that, due to its aristocratic origins, conservatism would disappear with the establishment of a competitive social order. On the contrary, everything suggests that ideologies possess a resilience that makes them largely independent of the social classes from which they may have originally emerged. In the specific case of conservatism, today it assumes a new guise as an ideology perfectly adapted to the context of a modern mass society. It presents itself in erudite form to academics, and in polemical and unchecked form to the masses, reaching a public that previous conservative generations had never dreamt of reaching - or indeed wanted to reach. It has shifted from the fundamentally aristocratic English conservative model, which oriented its thinking until recently, to the other model, North American and democratic based. The attempt to vulgarize conservatism in more academic spheres through the translation and dissemination of the works of Roger Scruton or Russell Kirk allows us to glimpse, however, the persistence of Anglophilia at the heart of American conservative thought itself, without prejudice to a more 'popular' conservatism.

For all these reasons, the new 'democratic' clothing does not seem to have sensibly altered the central aspects of the culturalist ideology, such as became established in the Ig6os during its fight against communism. An example is the philosopher Olavo de Carvalho, its most conspicuous current representative. Employing a verbal violence that the aristocratic Freyre lacked, Carvalho adapted the old Anglophile and aristocratic model that had guided previous generations of conservatives, like Alencar and Freyre, to another model, American and democratic, more palatable to the present-day. He does not reside in Oxford or smoke a pipe, or wear a tweed jacket or drink tea. He lives in Virginia, smokes cigarettes, collects guns and hunts animals. His conservative 'Americanism,' like the 'British' conservatism of Alencar or Freyre in the past, does not impede him from speaking in favour of Catholicism and the Iberian national formation and against the cultural decadence that the country has, in his view, experienced since the dissemination of Marxism through its intellectual spheres. It is also worth noting that, in polemical and impassioned 
form, Olavo de Carvalho (2010: 205-207) publicly defended Freyre's work in the first years of this century against what he called the "São Paulo sociology, Marxist and PT-ist, of Dr. Florestan Fernandes." There was no term of comparison between them: "What we have is a Freyrian sociology against a Stalinist doctrine legitimized ex post facto by a clumsy arrangement of methodological pretexts. The dispute only existed in the USP imagination, incapable of distinguishing between a universal genius and a state public functionary." The evidence that the cultural dispute over the interpretation of Brazil remains, now as in the previous century, an inseparable part of the political-ideological struggle of conservatism only reinforces the importance of studying it today as it re-emerges with a surprising vitality in the public sphere.

Thirdly and finally, it should be observed that, like all the other ideologies making up Brazilian political thought, culturalism possesses both positive and negative aspects. It is not the case here to make one more critique of Freyre - at this point, anachronistic and, why not say it? useless - for the conservative nature of his work, which is amply known. Here, on the contrary, we wish to highlight its ideologically positive side, revealing that Brazilian culturalist conservatism can and should not be condemned en bloc. The reason is simple. In a context, like Ibero-America, self-perceived as backward and peripheral, liberal cosmopolitanism and socialism invest in the radical critique of the national formation and the society resulting from it, exorcising the past as the accursed when present ills were gestated, in order to force a flight towards the future, the time of utopia towards which all hopes converge. The problem is that every attempt to realize a radical utopia, which involves the radical rupture with the existing order, inevitably involves a paradox since it can only be achieved by using elements taken from the very same order with which it aims to break (Houston, I993: I7). The radical utopian strategy tends to fail to the same extent that the paranoid rejection of the past impairs objective knowledge of the same and leads to an exacerbated repetition of the same errors in the form of its opposite - that is, a dystopia. The resulting frustration reinforces the mongrel complex, that is, a feeling of inferiority, producing an interminable vicious circle that ultimately undermines democratic collective action and feeds authoritarianism.

In this sense, despite its regressive power, Brazilian culturalist conservatism produced a feeling of positivity. Given that it is impossible for a national society to grow and develop in a conscious way without foundational or identificatory mythologies that serve positive narratives about itself, especially whether this society is recent, peripheral, backward and semi-colonial, authors like Alencar, Freyre, Nelson Rodrigues or Ariano Suassuna revealed through their intellectual production an extraordinary creativity in the formulation of an imaginary capable of functioning as a reference point for nationality. Their culturalism created a narrative of national formation that privileged what unites 
it rather than what separates it, what harmonizes it despite the country's violence and inequalities. This narrative created an imaginary of the Brazilian identity that gave meaning to the whole and helped reduce the inferiority complex and the pathological Eurocentrism of our elites concerning themselves and the population governed by them. For this reason, it is worth asking whether, in a peripheral country like Brazil, the culturalist nationalism of Freyre, despite his conservatism, did not perform an indispensable function by generating a sense of self-esteem without which any endeavour, even progressive, becomes impossible. So much so that the affirmation of his legacy was not limited to the conservative camps of Olavo de Carvalho. It was also promoted by liberals, like Roberto DaMatta, and socialists, like Darcy Ribeiro, who adapted it precisely to make up for the lack of a positive vision of the Brazilian people in the narratives of the ideologies represented by them, a vision essential to support them in democratic terms.

Received on 24/I/20I7 | Revised on 22/9/20I7 | Approved on 23/9/20I7

Christian Edward Cyril Lynch has a PhD in Political Science from the former University Research Institute of Rio de Janeiro (IUPERJ), the current Institute of Social and Political Studies of the State University of Rio de Janeiro (IESP-UERJ), where he is a professor, as well as the Veiga de Almeida University (UVA) and the Getulio Vargas Foundation (FGV). He is a researcher for the Casa de Rui Barbosa Foundation (FCRB), the National Council for Scientific and Technological Development (CNPq) and the Rio de Janeiro State Research Support Foundation (FAPERJ), as well as an honorary member of the Brazilian Historical and Geographic Institute (IHGB).

Pía Paganelli has a PhD in Literature from the National University of Buenos Aires (UBA). She is a professor of Brazilian Studies at the Faculty of Philosophy and Letters of UBA and holds a postdoctoral research award from the National Council of Scientific and Technical Research of Argentina (CONICET). 


\section{BIBLIOGRAPHY}

Araújo, Ricardo Benzaquen de. (1994). Guerra e paz: Casagrande \& senzala e a obra de Gilberto Freyre nos anos 30. Rio de Janeiro: Ed. 34.

Bastos, Elide Rugai. (2006). As criaturas de Prometeu. Gilberto Freyre e a formação da sociedade brasileira. São Paulo: Global.

Bastos, Elide Rugai. (2005). Raízes do Brasil-Sobrados e mucambos: um diálogo. Perspectivas, São Paulo, 28, p. I9-36. Botelho, André. (20ro). Passado e futuro dos ensaios de interpretação do Brasil. Tempo Social: Revista de Sociologia da USP, 22/I, p. 47-66.

Brandão, Gildo Marçal. (2005). Linhagens do pensamento político brasileiro. Dados - Revista de Ciências Sociais, Rio de Janeiro, 48/2, p. 23I-269.

Burke, Maria Lúcia Garcia Pallares. (2005). Gilberto Freyre: um vitoriano nos trópicos. São Paulo: Ed. Unesp.

Candido, Antonio. (1993). Recortes. São Paulo: Companhia das Letras.

Carvalho, Olavo de. (2010). Gilberto Freyre na USP. In: Falcão, Joaquim \& Araújo, Rosa Maria Barbosa de (org.). O imperador das ideias: Gilberto Freyre em questão. Rio de Janeiro: Topbooks.

Castro Gomes, Ângela. (2000). Gilberto Freyre: alguns comentários sobre o contexto historiográfico de produção de Casa-grande \& senzala. Remate de Males, 20/I, p. 47-57.

Costa Lima, Luiz. (1989). A versão solar do patriarcalismo: Casa-grande \& senzala. In: A aguarrás do tempo: estudo sobre a narrativa. Rio de Janeiro: Rocco, p. I87-237.

DaMatta, Roberto. (2013). O Brasil como morada: apresentação para Sobrados e mucambos. In: Freyre, Gilberto. Sobrados e mucambos: decadência do patriarcado rural $e$ desenvolvimento urbano. São Paulo: Global.

Feldman, Luiz. (20I6). Um clássico por amadurecimento: estudos sobre Raízes do Brasil. Rio de Janeiro: Topbooks.

Freeden, Michel. (2003). Ideology: a very short introduction. New York: Oxford University Press. 
Freyre, Gilberto. (2013). Sobrados e mucambos: decadência do patriarcado rural e desenvolvimento urbano. São Paulo: Global.

Freyre, Gilberto. (2002). Sobrados e mucambos. In: Santiago, Silviano (org.). Intérpretes do Brasil. V. II. Rio de Janeiro: Nova Aguilar.

Freyre, Gilberto. (1996). Manifesto regionalista. Recife: Massangana.

Freyre, Gilberto (1994). Discursos parlamentares. Brasília: Senado Federal.

Freyre, Gilberto. (1979). Tempo de aprendiz. São Paulo: Ibrasa/MEC (vol. I).

Freyre, Gilberto. (I967). Casa-grande \& senzala. I2 ed. Rio de Janeiro: José Olympio.

Houlston, James. (1993). A cidade modernista: uma crítica de Brasília e sua utopia. Tradução de Marcelo Coelho. São Paulo: Companhia das Letras.

Ianni, Octavio. (I989). Sociologia da sociologia. São Paulo: Ática.

Lamounier, Bolívar. (2006). Formação de um pensamento político autoritário na Primeira República. In: Fausto, Boris (org.). História geral da civilização brasileira. Tomo III: O Brasil Republicano. Rio de Janeiro: Bertrand Brasil.

Lynch, Christian Edward Cyril. (20I7). Conservadorismo caleidoscópico: Edmund Burke e o pensamento político do Brasil oitocentista. Lua Nova, São Paulo, Ioo, p. 313-352. Lynch, Christian Edward Cyril. (2016). Cartografia do pensamento político brasileiro: conceito, história, abordagens. Revista Brasileira de Ciência Política, Brasília, I9, p. 75-II9.

Mello, Evaldo Cabral de. (2010). O ovo de Colombo gilbertiano. In: Falcão, Joaquim \& Araújo, Rosa Maria Barbosa de (org.). O imperador das ideias: Gilberto Freyre em questão. Rio de Janeiro: Topbooks.

Mota, Carlos Guilherme. (1977). Ideologia da cultura brasileira. São Paulo: Ática.

Ramos, Alberto Guerreiro. (I995). Introdução crítica à sociologia brasileira. 2 ed. Rio de Janeiro: Ed. UFRJ. 
902

Ricupero, Bernardo. (2010). Sete lições sobre as interpretações do Brasil. São Paulo: Alameda.

Rios, José Arthur. (1996). Sobrados e mocambos. In: Fonseca, Edson Nery da (org.). Sobrados e mucambos: entendimento e interpretação. Recife: Massangana.

Santos, Wanderley Guilherme. (I978). Ordem burguesa e liberalismo político. São Paulo: Duas Cidades.

Souza, Jessé. (2000). Gilberto Freyre e a singularidade cultural brasileira. Tempo Social: Revista de Sociologia da USP, I2/I, p. 69-Ioo.

Vianna, Francisco José de Oliveira. (1974). Instituições políticas brasileiras. Rio de Janeiro: Record (Vol. I). 


\section{Palavras-chave \\ Periferia; \\ conservadorismo; \\ liberalismo; \\ iberismo; \\ nacionalismo.}

Keywords

Periphery; conservatism;

liberalism;

Iberianism; nationalism.

\section{O CONSERVADORISMO CULTURALISTA DE GILBERTO FREYRE: SOCIEDADE, DECADÊNCIA E MUDANÇA SOCIAL EM SOBRADOS E MUCAMBOS (1936)}

\section{Resumo}

O artigo busca aprofundar o conhecimento da vertente culturalista do conservadorismo brasileiro, iberista e católico, recorrendo para tanto à obra de Gilberto Freyre, principalmente, a Sobrados e mucambos. Buscaremos perceber como sua obra, recebida positivamente no contexto modernista, nacionalista e antiliberal da década de I930, por revelar as raízes e a "essência" ou "originalidade" da sociedade brasileira", passou a ser malvista no período posterior à Segunda Guerra Mundial, quando o processo de massificação e democratização da sociedade levou os setores mais radicalizados da classe média em expansão a se inclinar para o socialismo. Ao final, indicamos como um imaginário de pertencimento nacional, na forma de referentes positivos comuns, deveu-se em grande medida a autores como José de Alencar e Freyre.

\section{THE CULTURALIST CONSERVATISM OF GILBERTO FREYRE: SOCIETY, DECLINE AND SOCIAL CHANGE IN SOBRADOS E MUCAMBOS (1936)}

\section{Abstract}

This work aims to deepen the knowledge of the culturalist, Iberian and Catholic aspects of Brazilian conservatism, turning to the work by Gilberto Freyre, Sobrados e mucambos. We seek to understand how his work, positively received in the modernist, nationalist and anti-liberal context of the I930s due to its revealing of the roots and 'essence' or 'originality' of Brazilian society, fell into disfavour after the Second World War when the process of massification and democratization of society led more radical sectors of the expanding middle class to lean toward socialism. In concluding, we point out how an imaginary of national belonging, in the form of common positive referents, was due in large measure to authors such as José de Alencar and Freyre. 